\title{
The Effectiveness of Combination of Momordica charantia Extract and Averrhoa bilimbi on Nf-Kb Activation in Mice (Mus musculus) Balb/C Hyperglycemia Models
}

\author{
Intan Sartika Risky Sampurna ${ }^{1}$, Muhaimin Rifa' $\left.\right|^{2 *}$, Sri Rahayu ${ }^{2}$ \\ ${ }^{1}$ Magister Biology, Department of Biology, Faculty of Mathematics and Natural Sciences, Universitas Brawijaya, Malang, \\ Indonesia \\ 2Department of Biology, Faculty of Mathematics and Natural Sciences, Universitas Brawijaya, Malang, Indonesia
}

\begin{abstract}
Hyperglycemia is a medical condition when the blood glucose levels increase exceeds the reasonable limit. Hyperglycemia is a typical sign of diabetes mellitus (DM). Indonesia is the sixth-ranked country in the world after China, India, United States, Brazil, and Mexico. Treatment with herbs is currently being developed. Pare (Momordica charantia) and Belimbing wuluh (Averrhoa bilimbi) are plants that found around us. Some studies state that each of these plants can be anti-diabetic. The hyperglycemia can cause an immune system disorder characterized by pancreatic $\beta$ cell death involving IL-1 $\beta$, kappa B (NF)-KB nuclear factor, and Fas. The ability of NF-kB activation will affect the number of cytokines expressed by T cells, namely TNF- $\alpha$, and IFN- $\gamma$. The purpose of this study is to determine the effect of NF-kB activation on blood glucose levels in hyperglycemia mice. The results showed that the positive control treatment showed an increase in the number of NF-kB activations in CD4 and CD8 cells. EPBW (combination of Averrhoa bilimbi extract and Momordica charantia) administration results at a dose of $10 \mathrm{mg}^{\mathrm{kg}} \mathrm{k}^{-1} \mathrm{BW}$ showed a reduction in the amount of activated NF-kB as a substitute for the reduction. In addition, that dose can reduce blood sugar levels in mice hyperglycemia model.
\end{abstract}

Keyword: Averrhoa bilimbi, Hyperglycemia, Mamordica charantia, NF-kB.

\section{INTRODUCTION}

Hyperglycemia is a typical sign of diabetes mellitus (DM). Based on WHO data, 422 million people live with diabetes [1]. Diabetes is one of the autoimmune diseases caused by decreased insulin secretion by pancreatic $\beta$ cells [2]. The hyperglycemia will cause an immune system disorder characterized by pancreatic $\beta$ cell death. This cell death involves IL-1 $\beta$ and nuclear factor kappa B (NF-kB). The ability of NF-kB activation will affect the number of cytokines expressed by T cells, such as TNF- $\alpha$ [3].

Herbal treatment can reduce the risk of dependence, such as treatment using chemicals. Averrhoa bilimbi is a plant we can found around the people of Indonesia. Averrhoa bilimbi has several active substances, including antioxidants as anti-bacteria, anti-diabetes, and antiinflammatory [4].

Momordica charantia contains charantin, which can recover pancreatic beta cells. In addition, $A$. bilimbi as anti-hyperglycemic whereby giving ethanol extracts of $A$. bilimbi can affect the blood glucose levels of mice, that have hyperglycemia. Flavonoids are believed to be

\footnotetext{
* Correspondence address:

Muhaimin Rifa'i

Email : Immunobiology@ub.ac.id

Address : Dept. Biology, University of Brawijaya, Veteran Malang, 65145
}

antidiabetic substances as inhibitors of the alphaglucosidase enzyme that delay the absorption of carbohydrates so that the blood glucose levels will decrease [5]. Combining the two plants is expected to increase the effectiveness of active substances contained in the two plants. The purpose of this study is to determine the effect of EPBW on NF-kB activation and blood glucose level in mice with hyperglycemia model.

\section{MATERIAL AND METHOD}

This research was conducted from November 2019 to February 2020 in the Animal Laboratory of Malang State University, and the Laboratory of Physiology, Structure and Animal Development, Department of Biology, Universitas Brawijaya, Malang, East Java, Indonesia.

\section{Description of Tested Animals}

Tested animals used in this study were 25 $\mathrm{Bab} / \mathrm{c}$ mice with 6-week-old female sex obtained from the Animal Physiology Laboratory of Islamic University of Malang. The average weight of mice was $23 \mathrm{~g}$.

\section{Research Design}

This study used a Completely Randomized Design (CRD) with five treatment groups with five replications for each treatment. The treatments of this study were healthy control, pain control, and treatment with three different EPBW doses. Tested animals in the control group and treatment group were given streptozotocin (STZ) 
injections with a single dose of $145 \mathrm{mg} \cdot \mathrm{kg}^{-1} \mathrm{BW}$ dissolved in an STZ buffer with a $\mathrm{pH}$ of 4.5. After three days of the injection, fasting blood sugar from mice was measured. Mice for the treatment group were mice, which had blood glucose $<200$ $\mathrm{mg} \cdot \mathrm{dL}^{-1}$. The treatment group used three doses of combinations of EPBW in 10, 40, $160 \mathrm{mg} \cdot \mathrm{kg}^{-1}$ BW. Research design referred to the approval of the ethics commission number 1109-KEP-UB.

\section{Preparing EPBW}

The extract of $A$. bilimbi and $M$. Charantia were obtained from Materia Medika in Malang, East Java. The solvents used were ethanol 96\%, which is a solvent that has a group of hydroxyl, which is polar and group alkyl, which is non-polar so it can dissolve the entire secondary metabolites compound that contained in the plants [6]. The compound from bitter melon is a compound of three secondary metabolites that is polar or non-polar, so the organic solvent, such as ethanol $96 \%$, is needed. Ethanol extract can activate the flavonoid, saponin. By doing the extraction, crude extracts were obtained from the two plants [5]. Making EPBW were performed using a solvent of distilled water of $150 \mathrm{~mL}$ for each dose treatment. Making extracts were done every three days. The EPBW combination was given using a sonde adjusted to the weight of the mouse and carried out every day for 15 days.

\section{Cell Isolation of Spleen}

Mice that had been treated for 14 days were surgically removed to isolate cells from spleen organs by being crushed in PBS solution, then transferred in a $15 \mathrm{~mL}$ propylene tube. After all the spleens from the experimental animals were collected, centrifugation was carried out with a speed of $2500 \mathrm{rpm}$ and a temperature of $10^{\circ} \mathrm{C}$ for $5 \mathrm{~min}$. The supernatant from the centrifugation was removed, and pellets added with $1 \mathrm{~mL}$ PBS and homogenized.

\section{Antibody Staining and Flow-cytometric Analysis}

Flow-cytometric analysis performed using DB Cellquest Pro software. Intracellular cytokine staining was performed by a Cytoperm/Cytofix kit (BDBiosciences Pharmingen) according to the manufacturer protocol and modified by Rifa'i [7]. Staining that was used was FITC-conjugated rat antimouse $\mathrm{CD} 4, \mathrm{PE}$-conjugated rat-antimouse $\mathrm{CD} 25$ and $\mathrm{PE} / \mathrm{Cy} 5$ conjugated rat antimouse NF$k B$, FITC-conjugated rat antimouse CD4, PEconjugated rat- antimouse TNF- $\alpha$ and PE/Cy5 conjugated rat anti-mouse IFN- $\gamma$.

\section{Statistical Analysis}

Data analysis using BDCellQuest Pro software with testing with statistical analysis using one way ANOVA (Analysis Of Variance) using SPSS version 25. The results of the study were said to be significant if the results obtained were $p$ $<0.05$. If the results of the study are significant, further tests are conducted using Tukey Test.

\section{RESULT AND DISCUSSION EPBW Decrease The Activation of NF-kB in CD4 Cells}

The positive control group is a hyperglycemia $(\mathrm{K}+)$ mouse model of the relative number of CD4+ cells that express the highest NF-kB compared to the healthy control group (K-), which is $7.45 \%$ ( $p<0.05)$. The average healthy control was lower than the pain control that was $6.3 \%$ but significantly different from the average relative number of cells expressing NF-kB in the hyperglycemia mouse group P1 5.5\%, but not different in the $\mathrm{P} 2$ group by $6.3 \%$ and $\mathrm{P} 3$ of $6.9 \%$ as indicated by the notation in Figure 1.
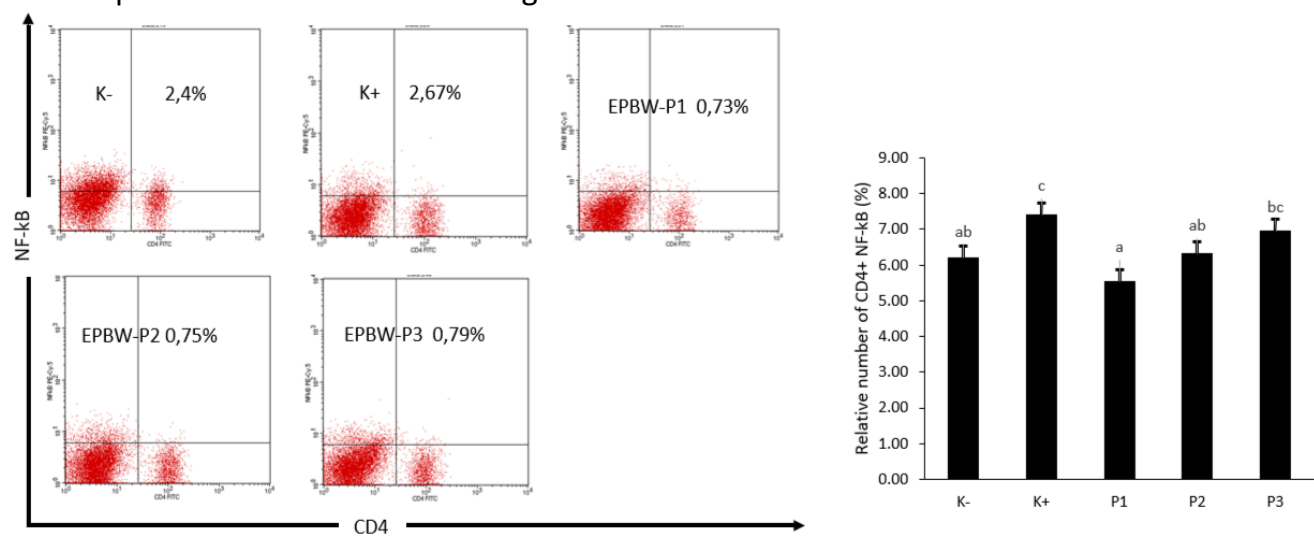

Figure 1. Graph of the Decreasing of NF-KB activation in CD4 cells in hyperglycemia mice. Note: $\mathrm{K}-=$ healthy control, $\mathrm{K}+=$ pain control, $\mathrm{P} 1$ = hyperglycemia mice model with a treatment dose of $10 \mathrm{mg}^{\mathrm{kg}}{ }^{-1} \mathrm{BW}, \mathrm{P} 2=$ hyperglycemia mice model with a treatment dose of $40 \mathrm{mg} \cdot \mathrm{kg}^{-1} \mathrm{BW}, \mathrm{P3}=$ hyperglycemia mice model with a treatment dose of $160 \mathrm{mg} \cdot \mathrm{kg}^{-1} \mathrm{BW}$. 

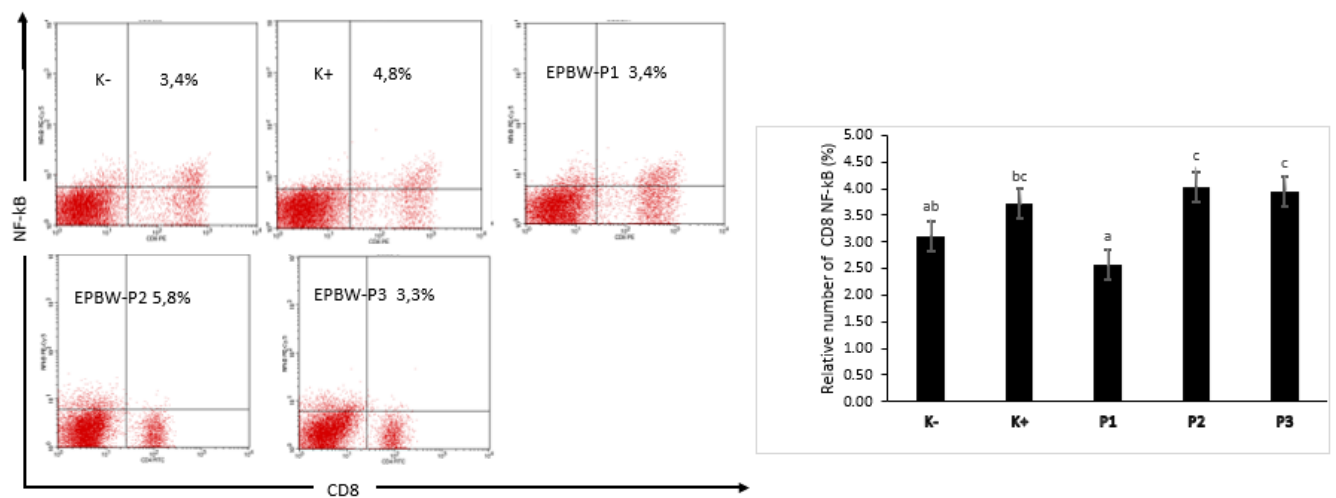

Figure 2. Graph of the Decreasing of NF-kB activation in CD8 cells in hyperglycemia mice. Note: $\mathrm{K}-=$ healthy control, $\mathrm{K}+=$ pain control, $\mathrm{P} 1=$ hyperglycemia mice model with a treatment dose of $10 \mathrm{mg}^{\mathrm{kg}} \mathrm{kg}^{-1} \mathrm{BW}, \mathrm{P} 2=$ hyperglycemia mice model with a treatment dose of $40 \mathrm{mg} \cdot \mathrm{kg}^{-1} \mathrm{BW}, \mathrm{P} 3$ = hyperglycemia mice model with a treatment dose of $160 \mathrm{mg} \cdot \mathrm{kg}^{-1} \mathrm{BW}$.

\section{EPBW Decrease The Activation of NF-kB in CD8 Cells}

The results of the analysis of flow cytometry and analysis of statistics of the number of NF-kB expressed from T lymphocyte CD8+ (Fig. 2). The positive control group, which is a hyperglycemia $(\mathrm{K}+)$ mouse model, the relative number $\mathrm{T}$ lymphocyte CD8+ cells that express NF-kB was the highest compared to the healthy control group (K-), in the amount of $3.1 \%(p<0.05)$. The average healthy control was lower than the pain control at $3.7 \%$ but significantly different from the average relative number of cells expressing NF-kB in the hyperglycemia mice model P1 group $2.5 \%$, but not different in $\mathrm{P} 2$ group by $4.04 \%$ and P3 3.9\% are indicated by the notation in Figure 2 .

\section{EPBW DecreaseThe Blood Glucose Level}

The results of measurement of blood sugar levels in hyperglycemia mice conducted every three days for 15 days of treatment showed a decrease. It is shown in Figure 3.

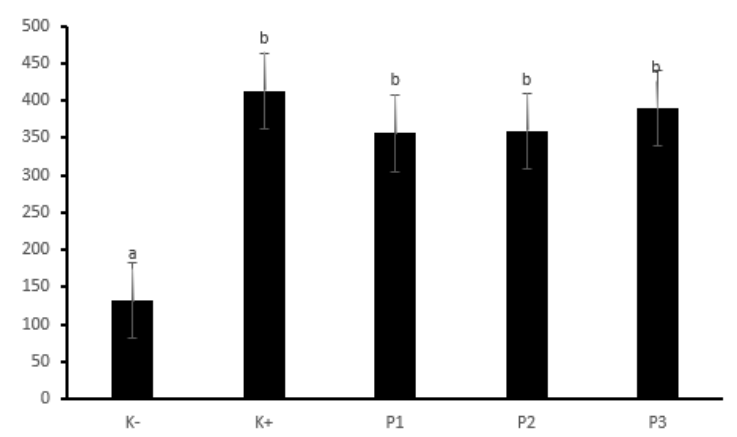

Figure 3. Graph of the decreasing fasting blood sugar levels. Note: $\mathrm{K}-=$ healthy control, $\mathrm{K}+=$ pain control, $\mathrm{P} 1$ = hyperglycemia mice model with a treatment dose of $10 \mathrm{mg} \cdot \mathrm{kg}^{-1} \mathrm{BW}, \mathrm{P} 2=$ hyperglycemia mice model with a treatment dose of $40 \mathrm{mg} \cdot \mathrm{kg}^{-1} \mathrm{BW}, \mathrm{P3}=$ hyperglycemia mice model with a treatment dose of 160 $\mathrm{mg} \cdot \mathrm{kg}^{-1} \mathrm{BW}$.
Negative control mice had blood sugar levels of $131 \mathrm{mg} \cdot \mathrm{dL}^{-1}$, whereas hyperglycemia model mice on positive controls had blood sugar levels of $413 \mathrm{mg} \cdot \mathrm{dL}^{-1}$. There was a decrease in all treatments with an average treatment of P1 356 $\mathrm{mg} \cdot \mathrm{dL}^{-1}, \mathrm{P} 2$ of $359 \mathrm{mg} \cdot \mathrm{dL}^{-1}$ and P3 $389 \mathrm{mg} \cdot \mathrm{dL}^{-1}$.

\section{Discussion}

The combination of EPBW extracts as an antidiabetic to reduce NF-KB activation, proinflammatory factors, and reduce blood sugar levels in hyperglycemia mice models. Hyperglycemia is one of the first symptoms of diabetes [7]. Diabetogenic effects on streptozotocin administration will be initiated by reactive oxygen species (ROS) through direct toxic effects on GLUT 2, the cytokine action of TNF- $\alpha$, and INF- $\gamma$ due to stimulation of dependent T cells. In response to streptozotocin, Th-1 type cytokines and other immune cells produce ROS that activates NF-kB [8].

The use of the hyperglycemia mice model treated with EPBW extract on CD4 and CD8 cells showed a decrease in the number of activated NF-kB. As in diagrams and tables, NF-kB regulates the expression of most immunomodulatory factors, including cytokines, chemokines, adhesion molecules, antimicrobial factors, cell cycle regulators, and cell survival factors [9]. The decreased activation of NF-kB in the treatment group will affect the proliferation and activation of $T$ and $B$ cells. Also, it will affect the number of cytokines such as (IL-1, IL-6, TNF- $\alpha$ ) that play a role in responding to the antigens or microorganisms and play a role in the inflammatory process [10].

Decreased amount of activated NF-kB will affect the number of cytokines produced during activation of NF-KB, a protein that can induce transcription of several types of genes. It can 
stimulate inflammation by inducing the production of various inflammatory mediators, such as TNF- $\alpha$, IFN- $\gamma$ [11].

STZ induction in the Hyperglycemia mice model can trigger necrosis because it is toxic as in previous studies, that STZ could destroy pancreatic islet through necrosis mechanism. The damage of pancreatic beta cells is characterized by an increase in fasting blood sugar [12]. EPBW contains several active compounds that can reduce blood sugar levels. The decrease of blood glucose levels in the hyperglycemia mice model was caused by several active compounds found in Momordica charantia, e.g. sitosteryl glucoside and stigmasteryl glucoside. The combination of these compositions forms charantin, which is a potential substance with antidiabetic properties [5]. In addition, charantin can stimulate insulin secretion. It is due to increased recovery of pancreatic $B$ cells because these substances can improve and inhibit pancreatic $B$ cell death [13].

The function of Saponins in EPBW is as antihyperglycemia agents by preventing glucose uptake in the brush border in the small intestine. Flavonoids are also one of the active substances contained in EPBW, which is an alpha-glucosidase enzyme inhibitor that is used to delay the absorption of carbohydrates so that the blood glucose levels will decrease [5].

\section{CONCLUSION}

The combination of EPBW in hyperglycemia mice gave good results in reducing the amount of NF-kB activation. It supported by the decrease in blood sugar levels of hyperglycemia mice. A dose of $10 \mathrm{mg} \cdot \mathrm{kg}^{-1} \mathrm{BW}$ is considered effective in reducing the amount of NF-kB activation as well as in reducing blood glucose levels in mice.

\section{REFERENCES}

[1] Minsitry of Health, Repuclic of Indonesia. 2018. Info datin pusat data dan informasi. Minsitry of Health. Jakarta.

[2] Almabrouk, S.K., N. Dwi, S. Rahayu, M. Rifa'i. 2019. The effect of Moringa oleifera leaves and VipAlbumin ${ }^{\circledR}$ on the immune system of diabetes mellitus balb/c mice model. J. Exp. Life Sci. 9(3). 170-175.

[3] Meadler, K., G.A. Spinas, P. Sergeev, M. Weber, A. Fontana, N. Kaiser, M.Y. Donath. 2001. Glucose induces beta-cell apoptosis via upregulation of the Fas receptor in human islets. Diabetes. 50(8). 1683-1690.
[4] Binti Hasim, N. 2014. Study on bioactive compound degradation from belimbing buluh (Averrhoa Bilimbi). Thesis. Faculty of Chemical and Natural Resources Engineering. Universiti Malaysia Pahang.

[5] Chanda, R., A. Samadder, J. Banerjee, C. Author. 2019. Anti-diabetic activity of Momordica charantia or bitter melon: a review. Acta Scientific Pharmaceut. Sci. 3(5). 2581-5423.

[6] Afifah, U.N. 2017. Uji aktivitas antidiabetes ekstrak etanol 96\% Buah Pare (Momordica charantia L.) terhadap tikus jantan galur wistar yang diinduksi aloksan. Study Program of Pharmacy, Faculty of Pharmacy, Muhammadiyah University of Surakarta. 1-13.

[7] Rifa'i, M., N. Widodo. 2014. Significance of propolis administration for homeostasis of CD4+CD25+ $T$ immunoregulatory cells controlling hyperglycemia. SpringerPlus. 3. 526.

[8] Lgssiar, A., M. Hassan, N. Friesen, F. Nicoletti, H. Gleichmann. 2004. Interleukin-11 inhibits NF-KB and AP-1 Activation in islets and prevents diabetes induced with streptozotocin in mice. Exp. Biol. Med. 15. 425-436.

[9] Oh, H., S. Ghosh. 2013. NF-kB: Roles and regulation in different CD4+ T-cell subsets. Immunol. Rev. 252(1). 41-51.

[10] Caamaño, J., C.A. Hunter. 2002. NF-kB family of transcription factors: Central regulators ofinnate and adaptive immune functions. Clin. Microbiol. Rev. 15(3). 414429.

[11] Dwijayanti, D.R., M.S. Djati, M. Rifai 2015. Decreasing the expression level of macrophage cell, pro-inflammatory cytokines and NF-kb by using Vipalbumin ${ }^{\circledR}$ in vitro. Asian J. Cell Biol. 10(2). 43-56.

[12] Zamroni, A., E. Zubaidah, M. Rifa'i, S.B. Widjanarko. 2018. Anti-hyperglycemia and immunomodulatory activity of a polyherbal composed of Sesbania grandiflora, Salacca zalacca and Acalypha indica. J. Exp. Life Sci. 8(3). 184-192.

[13] Joseph, B., D. Jini. 2013. Antidiabetic effects of Momordica charantia (bitter melon) and its medicinal potency. Asian Pac. J. Trop. Dis. 3(2). 93-102 